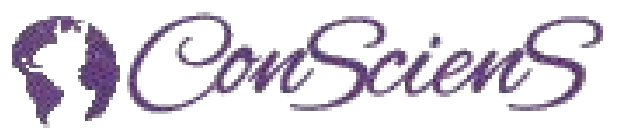

DOI: $10.5281 /$ zenodo.4058769

\title{
Value at COVID-19: \\ Digitalized Healthcare, Luxury Consumption and Global Education
}

\author{
Julia M. Puaschunder ${ }^{1}$ \\ ${ }^{1}$ The New School, Parsons School of Design, Department of Economics, 6 East $16^{\text {th }}$ Street, $9^{\text {rd }}$ floor 89, New \\ York, NY10003,USA, Julia.Puaschunder@newschool.edu, T 001212229 5700, F 0012122295724, \\ www.juliampuaschunder.com \\ ${ }^{2}$ Columbia University, Graduate School of Arts and Sciences, Julia.Puaschunder@columbia.edu, \\ http://blogs.cuit.columbia.edu/jmp2265
}

\begin{abstract}
The new Coronavirus (COVID-19) accounts for the most severe health and economic threat since about a century. The human, medical and economic shock with major fallout in social, humanitarian and international development domains is the most tragic event having occurred since the Great Plagues of the medieval times, the Great Depression and the two World Wars. Yet in every crisis and lasting economic, societal and humanitarian shock, there are always positive externalities as well. While the author foremost respects the more important literature on the tremendous negative consequences and hidden inequalities and unnoticed despairs of COVID-19, this paper sheds heterodox light on the positive externalities and economic growth potential of the Great Pandemic of 2019. Three positive outcomes of the novel Coronavirus pandemic are captured in a foresighted outlook: (1) A digitalization disruption with particular focus on healthcare, preventive medicine and whole-rounded, ecofriendly lifestyles is perpetuated by COVID-19. (2) As in previous pandemics, luxury consumption that is prospected to flourish after consumption constraints and lockdown endurance may play a role in driving economic growth in the post-COVID-19 world. (3) Digitalized education and conglomerates in the educational sector may lead to universities becoming truly global temples of information exchange. The paper closes with potential ethical imperatives to ennoble our prospected future post-COVID-19 world to come. Overall, this paper aims at providing a glimpse of hope in despair and grievance over COVID-19 and advocates for equal access or redistribution of the merits of the gains from COVID-19 for living the dream of a better, more beautiful society than COVID-19 has hit before.
\end{abstract}

Keywords: Access to education, Coronavirus, COVID-19, Digitalization, Economics, Education, Equalizer, Healthcare, Luxury, Medicine, Pandemic, Technology, Value

\section{COVID-19}

The new Coronavirus (COVID-19) is an infectious disease that was first diagnosed in Wuhan, China, in December 2019. The majority of infected only develops mild symptoms such as fever, cough, difficulty breathing and tiredness as well as loss of smell and taste, but also rashes and other diffuse symptoms (Center for Disease Control and Prevention 2020). Depending on age and prevalence, COVID-19 can lead to acute complications such as organ failure, cytokine loads, blood clots and septic shock (Center for Disease Control and Prevention 2020). Pre-existing conditions, such as obesity and diabetes, but also the general status of the immune system, are crucial determinants whether the new Coronavirus is of severe danger to the individual (Salzburg Declaration 2020). Prevention and holistic medicine play an important role whether the disease turns out to follow a mild or severe symptom trajectory (EcoWellness Group 2020). 
In January 2020, the World Health Organization declared a state of emergency with international relevance over COVID-19, and in March 2020 the outbreak of a global pandemic. As of September 2020, almost 35 million infected cases are known and almost one million deaths have been recorded in over 200 countries in all six World Health Organization territories (Sachs, Horton, Bagenal, Amor, Caman \& Lafortun 2020). Exponentially growing numbers of infections and a lack of an effectively-tested vaccine or completely-curing medication so far project that there may not be a fast end to the crisis in the near future (United Nations 2020).

\section{Economic growth potential}

The COVID-19 pandemic is an external shock that implies tremendous negative consequences ranging from human health risks to economic shortfalls and sociopsychological despair. Already now, the novel Coronavirus caused a dramatic downturn for general mobility and international tourism including gastronomy (Gössling, Scott \& Hall, 2020; Puaschunder, Gelter \& Sharma, 2020). In April 2020, more than half the world's population resided in countries enforcing lockdowns, which disrupted individual lives, business activities and international mobility (International Monetary Fund 2020). All major world economies suppressing human social interaction, which spilled over into an economic decline around the globe comparable to the onset of the Great Depression (Sachs et al. 2020; UNDP 2020). In the wake of "social distancing" measures, consumption decreased by $32 \%$ in China, $49 \%$ in Germany and $50 \%$ in the US as well as $78 \%$ in Great Britain (Jones, Palumbo \& Brown 2020). The Financial Times Stock Exchange Group, Dow Jones Industrial Average and Nikkei plummeted in the first quarter of 2020 drastically (Jones et al. 2020). Unemployment and furloughs rose in all major market economies (Jones et al. 2020). The International Monetary Fund (2020) estimates a 5-15\% chance of a recession after the first quarter of 2020 measured by Gross National Product (Sachs et al. 2020). The world economy shrunk by $3 \%$ in the first quarter and is expected to decline around 5\% throughout 2020 (IMF 2020). The 2021 global growth is projected at 5.4\%, which leaves the 2021 GDP some 6.5 percentage points lower than in the pre-COVID-19 projections of January 2020. All these measures resemble the onset of the Great Depression of the 1930s, which - together with subsequent events - changed the corporate governance structure and conduct dramatically, unprecedentedly and lastingly (Sachs et al. 2020; Gelter \& Puaschunder forthcoming).

Despite the enormous economic growth decline already obvious and prospected in the years to come, there are also positive externalities of COVID-19 that includes attention to preventive healthcare coupled with digitalization; zest for excellence luxury consumption in light of human suffering, consumption restrictions and lockdown endurance as well as digitalized education with a truly international outlook.

\section{The value of preventive medicine in the digital age}

A prospective post-COVID New Age Renaissance will advance healthcare (Piper 2020; Puaschunder 2019b). With the COVID-19 pandemic, the connection between preventive medicine, general health and prevalence has gained attention. Due to a weakened immune system being related to a severe disease trajectory, preventive medical care has become more important for emergency medicine. In the novel Coronavirus crisis, prevention and general, holistic medicine determine whether COVID-19 puts patients on a severe or just mild symptom trajectory. Obesity, but also the general status of the immune system are decisive in whether the Coronavirus becomes a danger for the individual.

In light of the heightened health risks of COVID-19, employers will naturally select healthier workers that may have to positive externality effect of an overall more productive 
labor at work (Gelter \& Puaschunder forthcoming). Already now elder and chronic patients' passing and vulnerabilities risks change labor market demand towards favoring young, healthier and Corona-survivors, who may benefit from a natural immunity, and being more virusresistant (Schwartz Center for Economic Policy Analysis Older Worker's Report 2020). Needless to say, the expected economic growth potential should also be considered to be taxed and the extra fiscal space used to offset the socio-economic losses and social misery implied in inequalities in market selection.

As for outside working conditions, those corporations that are placed in benevolent health-promoting territories will have a competitive advantage and gain in terms of labor quality (Puaschunder forthcoming c; Puaschunder \& Beerbaum 2020). Countries around the world are currently paying attention to preventive medical care in the wake of pandemic outbreak monitoring. Those nations that can offer technological advancements to monitor pandemic outbreaks but also medicine of the future that helps prevent diseases instead of just treating their consequences will produce positive labor advantages (Salzburg Declaration 2020).

On the corporate level, those corporations that manage to build a healthy environment that is attentive to prevention will gain from COVID-19 on the long run. Corporations that invest in hygiene but also group learning and team skills of hygienic working conduct will likely see a long-term labor-driven economic growth. In light of pre-existing conditions and obesity determining the likelihood of severity trajectory, corporations may also focus on fostering a healthy and ecological diet of their employees. Measures that can guarantee continued health in employment will account for corporate success and economic growth. Corporate governance could therefore foster self-monitoring of the state of health of employee and the comprehensive prevention in a holistic lifestyle. For instance, the German Prevention Act of 2015 of the German Federal Government compensates corporations to foster prevention in preventive self-care but also team learning of healthy lifestyles in the workforce, acknowledging the power of preventive care for economic productivity. Focusing on collective health as a common good will on the long run make labor components more productive. All these means of a hygienic environment, healthy preventive care and workplace interactions may be summed up in learning-by-preventing economic growth potential.

What is new these days is the entry of artificial intelligence (AI), algorithms and large data sets into the medical field, which raise prevention to a new level. As early as November 2019, experts identified new technologies such as robots, AI, algorithms and large datagenerated findings as helpful innovations in the medical sector (Puaschunder 2019e, f). Customized data-driven preventive medicine is considered to be one of the most groundbreaking achievements of today's medicine (Puaschunder 2019f). Efficiency, precision and better quality work are highlighted as advantages of AI, robots and big data in healthcare. Decentralized preventive medicine and telemedicine enable personalized preventive care that makes health more accessible to large parts of the population (Puaschunder 2019f). The power of big data aids our understanding of group behavior and trend predictions as well as preventive health care - such as through genetic predisposition and origin tests in the USA and handpicked genetic material selection. Health apps target at preventing COVID. Bluetooth-tracking of medical devices helps overcome bottlenecks and fraud while protecting privacy. Telemedicine cures remotely. Future global digitalized healthcare innovations are likely to come from corruption-free AI pioneering countries that tend to have better general medical care (Puaschunder 2020; Puaschunder \& Beerbaum 2020). Internet connectivity and AI-human-compatibility are growing competitive advantages (Puaschunder 2019g).

Puaschunder (forthcoming c) compiled three indices in order to compare international differences in digitization, economic potential, anti-corruption and access to good public medical care. Different aspects and combinations of artificial intelligence and economic growth, freedom from corruption and public health care showed that digitized connectivity as a proxy for artificial intelligence goes hand in hand with freedom from corruption, which in 
turn is correlated with good medical care (Puaschunder forthcoming c). These nations and especially Europe in an international comparison have the best prerequisites for a leadership role in global pandemic containment and risk management through new technologies in medicine but also to be able to offer predictive prevention excellence to the entire world (Puaschunder forthcoming c).

Based on macroeconomic modelling, Puaschunder and Beerbaum's (2020) empirical research brought forward four indices shedding light on health inequality in the $21^{\text {st }}$ digital century. International data on digitalization, economic prosperity, healthcare standards and innovation market financialization revealed that Europe and North America feature excellent starting positions on economic productivity and relatively low levels of corruption. Internet connectivity and high Gross Domestic Product are likely to lead on AI-driven big data insights for pandemic prevention, of which Europe, Asia and North America have optimal global healthcare leadership potential. Europe benefits from highest standards on public preventive medical care, while the United States has the most prosperous market financialization to advance medical innovations. Oceania performs well on general healthcare but has comparatively less international medical market power. Asia and the Gulf region are in the middle ranges of healthcare provision and market innovation financing but are critical on corruption, which also appears to hinder access to quality healthcare in South America. Africa ranks low on healthcare and raising funds for medical purposes in corruption-prone territories.

\section{Luxury}

From a socio-psychological point of view, crises and proximity to death and illness lead to eccentric consumption and price insensitivity (Bourdieu 1979/2010; Schmelzing 2019). Historically, the time after the great plague of the 14th century was characterized by extraordinary luxury consumption, which advanced the Middle Ages into the Renaissance (Keynes 1936; Making Marvels 2019; Piper 2020; Schmelzing 2019; Veblen 1899). The survivors' joie de vivre and self-determination were released in industrial enthusiasm with a focus on the now and here in the renunciation of fatal religious obedience (Piper 2020; Schmelzing 2019). Thanks to low inflation and social change, luxury became affordable for larger parts of the population who - after a period of death, physical suffering and emotional deprivation - refreshed themselves in the joys of life (Piper 2020; Schmelzing 2019). Cities flourished, trade pulsed, and intellectual-driven innovations dominated social progress.

From the Renaissance to absolutism, luxury was enjoyed in the form of a figure that was more than its individual parts. Luxury was socially accepted if it was linked to a social identity that included a collectively shared experience as well as unique new innovations that signaled a mastery of nature and the environment (Making Marvels 2019; Puaschunder 2020c; Rousseau 1750; Serdari 2016; Tajfel \& Turner 1979).

Future booming industries may include luxury spending on health and prevention, which not only promotes general health in society but also drives economic growth (Puaschunder 2019a). In the digital age of social media, luxury could force more comprehensive health prevention based on big data. In contrast to other types of consumption, large amounts of data enable exponential basic benefits to be generated. A bit more information therefore has exponentially growing added value, which in the medical field appears particularly helpful for finding connections and behavioral patterns in prevention (Schumpeter 1934). Consumption of information is also not exclusive - reading information and learning from it does not diminish someone else's chances or diminish their consumption (Puaschunder 2018a, 2019a, c). Information consumption on the internet could become an environmentallyfriendly luxury. Future innovations in the medical field are predestined for digitized health care and self-monitoring with the help of electronic self-measuring devices. Self-monitoring devices and big data insights can provide uniquely valuable educational work for individuals who need 
to be encouraged to lead a holistic lifestyle focused on prevention. Coupled with insights derived from big data in the extrapolation and in relation to society, computational power in the digital age can become a preventive healthcare luxury moment.

Luxury society enjoys in (1) a Gestalt greater than its components; (2) serving the common good fostering social identity in collectively-shared experiences; and (3) groundbreaking innovations demonstrating mastery over nature of the world (Making Marvels 2019; Puaschunder 2020c; Rousseau 1750; Serdari 2016; Tajfel \& Turner 1979). Antidiscrimination efforts must protect excellence (Puaschunder forthcoming b). Contrary to naturally-constrained, saturable consumption of ordinary goods with declining marginal utility, data transfer online offers exponentially-increasing marginal utility of information in network effects and non-rivalrous consumption of information alongside exponentiallyincreasing multi-procal emotional gratification in world-wide virtual collective experiences (Puaschunder 2018b). One of the most powerful ways to enjoy luxury in the digital age is online education, which now has leveraged into a truly international experience.

\section{Intellectual conglomerates in virtual spaces}

COVID-19 unleashed the online technology world. Physically distanced, we became digitally closer than ever. On a flat globe, data traffic exploded. A multi-tasking online workforce gained global outreach and flexibility in digitalization cutting red tape (Puaschunder 2020d). The digitalization trend has become prevalent in education. Since the outbreak of the 2019 novel Coronavirus crisis, COVID-19 entailed massive changes in the education sector (Corlatean 2020). Teachers, pupils and students, parents, schools and local communities and, last but not least, the state were suddenly put in a position to change their rules of operation, teaching techniques or examination methods (Corlatean 2020).

With most university campuses around the world currently performing a speedy transition to online teaching and remote learning, it is certain that hybrid learning and online classwork will be perks that last forever, even after COVID-19 will have its influence on our behavior. Disruptive technology use will enable universities to cater to the whole world on education at lower cost and offering more flexibility that attracts students without any consideration of their location. The actual on site work will be focused on research, while learning will be more likely to happen online in the virtual space. Large consortia that allow swapping and sharing courses within the larger online consortium will take over.

Disruptive technologies will be effective at helping students around the globe and open doors for studying "abroad" to everyone. Taking classes remotely will not cost as much as physical relocation did in the past. Classes will also open up free from visa and administrative hurdles. So the digitalization disruption may become a great equalizer that opens access to elite education to previously politically unfavorable visa applying nationals. Education therein has the potential to be the great equalizer international development has wished for ever since. Future partnerships of the technology and universities governed by international institutions will offer a broad range of hybrid online-offline teaching solutions in ample virtual spaces that serve as truly international educational hubs.

Access to virtual consortia will also offer the opportunities to cherry-pick an individualized education based on interests and afar from physically reachable learning repertoires. Mass teaching with a cohort of similarly educated will pass for a new cadre of individualized and highly specialized graduates that could select very individualized study schedules. For this, the institutional support and openness to accept courses within the conglomerate consortium has to be emphasized. But with the currently ongoing digitalization disruption requiring more and more refined skills in a world where the gap between skilled and unskilled labor has become the widest, the time for refined and individualized education appears to have come. 
In addition, universities with students that do not have to be attending campus classes not only can offer flexible education with broad international outreach. Not having to be on one particular campus offers two flexibilities: international but also over time. Online classes can be attended by people from around the world. But also with no relocation costs and visa requirements having to be met, individuals are able to remain in education longer and more flexibly. Online degrees that can be acquired over long time become reasonable if people only have to attend a week a year, during which they may choose to get educated on a specific subject they need right at the moment in time in their career. Imagine signing up for a 10 year MBA program that is completed with one course per year over a decade. The advantage would be a long-term bond with education institutions and temporally flexible education - picking educational contents at the right moment in time in one's career. Especially in highly flexible fields, such as IT, medicine or law, in which constant education is mandatory and/or necessary, an as such long-term online degree would be beneficial. In addition, the signing up for such a long term degree accomplishment process may be easier as it stretches out reduced online costs. Further, the emotional bond to institutions may grow over the long term, and educational and reputational capital can be maximized to be harvested for a long time.

A market polarization is expected, in which the big conglomerates may swallow smaller and financially weaker colleges. The universities that will likely offer these kind of programs are the large Ivy Leagues, who can wait out the pandemic given large endowments, constant stream of funding from alumni and students drawn from waitlists. These are the ones that will outwait the smaller and lower tier colleges that are dependent on tuition. Being flexible to adapt and partner with technology providers but also in a favorable location will likely be beneficial features of the universities of tomorrow. These universities surviving the COVID-19 crisis will be able to expand their enrollment dramatically, once they transitioned effectively into remote online teaching and the market has accepted this new normal. Universities that are not able to adapt to online teaching or are not even close to a consortium solution are expected to be in trouble.

While the affordability of entering these virtual spaces will serve as a great equalizer offering access to affordable education around the globe, there may be the risk of an inflation of many degrees offered to students without any space constraints and a discreditation of already existing degrees lurking. Additional problems arise from missing real in-person learning and on-campus networking opportunities. Children staying with their parents to take classes may grow up less attentive to be around people their age, and there may be the risk of social isolation, heightened levels of depression and a generation of socially awkward geeks without empathy coming up in contrast to students that have had the real world learning experience in

classrooms. However, if we can lower the cost of education for the upcoming generation, the educational debt burden may be lifted that was recently referred to by the New York Federal Reserve as to be putting generation internship into a prison of debt from which they cannot escape even after graduation. Virtual learning experiences may also shun students from all social-psychological burdens and peer-pressure downfalls of on-campus education if we manage to create virtual spaces upholding a healthy climate of online exchange grounded in mutual respect, ennobling culture of ethics and embracing diversity in elevating levels of inclusiveness.

\section{Discussion}

International preventive solutions against the current Coronavirus lie in finding joint solutions to contain the pandemic. Global disease prevention should be guided by innovative artificial intelligence and algorithm-supported digital tracking. Digitization and big data-based human decision-making aids enable unique, never-before-seen trend analyzes and risk prevention mechanisms. Since the status of artificial intelligence varies widely across the globe, so-called 
data hubs, in which artificial intelligence is used to an advanced degree, but at the same time freedom from corruption also offers generally favorable conditions for prevention diagnostics, trend analyzes and risk prevention, should ensure global health. These technology pioneers have high internet connectivity, which is often used as a proxy for general digitization, an excellent general health check-up and medical care that is awarded fairly and free of corruption (Puaschunder forthcoming b). These artificial intelligence health centers should take global leadership against pandemics in the international tracking of health information (Puaschunder forthcoming b).

Taxing data transfer and generating profit with data and targeted advertising in the digital age should generate fiscal leverage to cushion societal losses through social inequality and to promote a general health network more strongly. While the European Commission is planning a new type of taxation of digital profits of 3\%, European nation states are still unclear about its implementation. As reported by the New York Times, Austria is a pioneer in the attempt to tax data transfer. With the planned digital tax, Austria could set international standards around the world. Taxation could also curb innovation and lead to the monopoly of large data collection companies. Any country or location that was the first to implement a data tax would suffer. So what would be needed would be a Europe-wide or international implementation of data taxation. Whereby no nation dares to take the first step in order not to be thrown back in the general competition. The one who clearly loses to untaxed data commercialization is the general population. Because taxation of data transfer could cushion the negative consequences of the market entry of artificial intelligence. Tax revenue from taxing data transfer could thus catch market losers from the use of new technologies. Financial strength could help to retrain workers and create the institutional framework to train citizens to get involved with new technologies and to use them successfully. At the same time, financial resources could also offer the necessary training opportunities to carefully prepare consumers for an informed decision about digital information exchange and knowledge gain on the Internet. Protection of particularly vulnerable population groups, such as the sick and the mentally weak, is a matter of concern here in order to achieve a human and ethical introduction of new technologies.

The new approaches to teaching and learning also imply novel inequalities in regards to private learning spaces and access to information dependent on the level of digitalization and internet connectivity. With access to healthcare and education in virtual luxury boutiques we need to rethink democratization of internet access and online availability. Public and private sector forces on the local, national, international and global levels should bundle and crosspollinate to find create ways in embracing the masses equally with connectivity. Ethical cliffs of online access and technology affinity determining access to health, education and emotional well-being should be outlined in order to avert societal downfalls.

In the future, ethical limits of privacy and the democratization of information should also be considered (Puaschunder 2017a, b, d, 2018b, 2020a, forthcoming a). It remains on young tech-entrepreneurs, breaking the most innovative waves to implement the New Age Renaissance in the Digital Age whilst upholding highest ethical standards (Puaschunder 2017c). To boldly envision, design and craft the virtual luxury platforms of tomorrow connecting us for collective information exchange fueled by emotions. But the beauty of enjoying lavish network effects and delving into world-wide collective emotional feasts also bears a responsibility to worship our common virtual luxury temples together wisely, conscientiously and sustainably (Puaschunder 2019d, 2020a, b).

\section{References}

Bourdieu, Pierre. 1979/2010. Distinction: A social critique of the judgement of taste. London: Routledge. Corlatean, Titus. 2020. "Risks, discrimination and opportunities for education during the times of COVID-19 pandemic." Proceedings of the $17^{\text {th }}$ RAIS Conference, June 1-2, 2020. 
Gössling, Stefan, Daniel Scott \& C. Michael Hall. 2020. Pandemics, tourism and global change: a rapid assessment of COVID-19, forthcoming in JOURNAL OF SUSTAINABLE TOURISM. DOI: 10.1080/09669582.2020.1758708.

Interdisciplinary Conference on 'System change?! The chance of transformation of the healthcare system: Analysis and chances of the coronavirus crisis, July 14-15, 2020, ECOWELlness GrouP, https://www.oekowellness.de/laenderuebergreifende-konzerenz-zum-thema-system-change-diechance-der-transformation-des-gesundheitswesens-14-07-2020/ (last visited August 12, 2020).

Jones, Lora, Daniele Palumbo \& David Brown, Coronavirus: A visual guide to the economic impact, BBC NEwS, https://www.bbc.com/news/business-51706225 (June 30, 2020).

Making Marvels: Science \& splendor at the courts of Europe Exhibition Catalogue. Koeppe, Wolfram (ed). 2019. New York: The Metropolitan Museum of Art,

Maynard, Keynes, John. The general theory of employment, interest and money. London: Macmillan, 1936.

Older Workers Report: Over Half of Unemployed Older Workers at Risk of Involuntary Retirement, THE SCHWARTZ CENTER FOR ECONOMIC POLICY ANALYSIS, https://www.economicpolicyresearch.org/jobsreport/over-half-of-older-workers-unemployed-at-risk-of-involuntary-retirement (August 5, 2020).

Piper, Nikolaus. 2020. Die Ökonomie des Todes. Süddeutsche Zeitung, April 10, 2020. Retrieved at https://www.sueddeutsche.de/wirtschaft/pest-coronavirus-wirtschaft-1.4873813.

Puaschunder, Julia Margarete. 2017a. "Nudging in the digital big data era." European Journal of Economics, Law and Politics 4(4): 18-23.

Puaschunder, Julia Margarete. 2017b. "Nudgital: Critique of a behavioral political economy." Archives of Business Research 5(9): 54-76.

Puaschunder, Julia Margarete. 2017c. "Nudgitize me! A behavioral finance approach to minimize losses and maximize profits from heuristics and biases." International Journal of Management Excellence 10(2): 12411256.

Puaschunder, Julia Margarete. 2017d. "The nudging divide in the digital big data era." International Journal of Research in Business, Economics and Management 4(11-12): 49-53.

Puaschunder, Julia Margarete. 2018a. "Dignity and utility of privacy and information sharing in the digital big data age." International Journal of Commerce and Management Research 5(4): 62-70.

Puaschunder, Julia Margarete. 2018b. "Towards a utility theory of privacy and information sharing and the introduction of hyper-hyperbolic discounting in the digital big data age." International Journal of Strategic Information Technology and Applications 10(1): 1-22.

Puaschunder, Julia Margarete. 2019a. "Artificial diplomacy: A guide for public officials to conduct Artificial Intelligence." Journal of Applied Research in the Digital Economy 1: 39-45,

Puaschunder, Julia Margarete. 2019b. "Artificial Intelligence, big data, and algorithms in healthcare." Report on behalf of the European Parliament European Liberal Forum in cooperation with The New Austria and Liberal Forum, Retrieved at https://papers.ssrn.com/sol3/papers.cfm?abstract_id=3472885.

Puaschunder, Julia Margarete. 2019c. "Artificial Intelligence Evolution: On the virtue of killing in the Artificial Age. " Journal of Sociology 3(1): 10-29.

Puaschunder, Julia Margarete. 2019d. "Artificial Intelligence market disruption." Proceedings of the International RAIS Conference on Social Sciences and Humanities, MD, United States, June 10-11, pp. 1-8,

Puaschunder, Julia Margarete. 2019e. "On Artificial Intelligence's razor's edge: On the future of democracy and society in the artificial age." Journal of Economics and Business 2(1): 100-119.

Puaschunder, Julia Margarete. 2019f. "Stakeholder perspectives on Artificial Intelligence (AI), robotics and big data in healthcare: An empirical study." Retrieved at https://papers.ssrn.com/sol3/papers.cfm?abstract_id=3497261.

Puaschunder, Julia Margarete. 2019g. The legal and international situation of AI, robotics and big data with attention to healthcare. Reports on behalf of the European Parliament European Liberal Forum in cooperation with The New Austria and Liberal Forum. Retrieved at https://papers.ssrn.com/sol3/papers.cfm?abstract_id=3472885.

Puaschunder, Julia Margarete. 2020a. Data fiduciary in order to alleviate principal-agent problems in the artificial big data age. 46th Eastern Economic Association Conference, Boston Sheraton, Boston, Massachusetts, United States, February 29.

Puaschunder, Julia Margarete. 2020b. On freedom in the artificial age. Retrieved at https://papers.ssrn.com/sol3/papers.cfm?abstract_id=3544348.

Puaschunder, Julia Margarete. 2020c. Making marvels: A reading: Review of making marvels exhibit at The Metropolitan Museum of Art, New York, New York. Luxury: History, Culture, Consumption, 1-16.

Puaschunder, Julia Margarete. 2020d. "Revising growth theory in the Artificial Age: Putty and clay labor." Archives in Business Research 8(3): 65-107. 
Puaschunder, Julia Margarete, Martin Gelter \& Siegfried Sharma, 2020e. COVID-19 Shock: Socio-technical, legal, corporate, economic and governance changes, PROCEEDINGS OF THE $18^{\mathrm{TH}}$ RESEARCH ASSOCIATION FOR INTERDISCIPLINARY STUDIES CONFERENCE ON SOCIAL SCIENCES AND HuMANITIES, (August 17, 2020)

Puaschunder, Julia Margarete. forthcoming a. "Big data ethics." Journal of Applied Research in the Digital Economy 1: 55-75.

Puaschunder, Julia Margarete. forthcoming b. "Overambition as disability: Discrimination of excellence." 19th Research Association for Interdisciplinary Studies (RAIS) conference at Princeton University, Princeton, New Jersey, United States, October 18-19, [Held online due to COVID-19].

Puaschunder, Julia Margarete. forthcoming c. "The future of Artificial Intelligence in international healthcare: Integrating technology, productivity, anti-corruption and healthcare interaction around the world with three indices." Journal of Applied Research in the Digital Economy.

Puaschunder, Julia Margarete \& Dirk Beerbaum. (forthcoming). Healthcare inequality in the digital $21^{\text {st }}$ century: The case for a mandate for equal access to quality medicine for all. Proceedings of the Unequal World Conference of the United Nations, United Nations New York, New York, United States.

Puaschunder, Julia Margarete \& Martin Gelter. forthcoming. COVID-19 and Comparative Corporate Governance. Journal of Corporation Law.

Rousseau, Jean-Jacques 1750. Discours sur les sciences et les artes. Geneva: Barillot.

Sachs, Jeffrey D., Richard Horton, Jessamy Bagenal, Yanis Ben Amor, Ozge Karadag Caman \& Guillaume Lafortun. 2020. The Lancet COVID-19 Commission, THE LANCET (July 9, 2020), https://www.thelancet.com/pdfs/journals/lancet/PIIS0140-6736(20)31494-X.pdf, https://doi.org/10.1016/S0140-6736(20)31494-X.

Salzburg Declaration, EcoWellness Group ICQ on behalf of the World Economic Forum Reset Programme.

Schmelzing, Paul. 2020. Eight centuries of global real interest rates, $R-G$, and the 'suprasecular' decline, 13112018. London: Bank of England Staff Working Paper No. 845. Retrieved at https://www.bankofengland.co.uk/-/media/boe/files/working-paper/2020/eight-centuries-of-global-realinterest-rates-r-g-and-the-suprasecular-decline-1311-2018.

Schumpeter, Joseph Alois. 1934. Die Theorie der wirtschaftlichen Entwicklung. Cambridge, MA: Harvard University.

Serdari, Thomaï. 2016. “Experiments in suchness: Hiroshi Sugimoto's silk Shiki for Hermès.” In J. Armitage \& J. Roberts (Eds.), Critical Luxury Studies: Art, Design, Media. Edinburgh: Edinburgh University Press, pp. $130-150$.

Symptoms of Coronavirus Disease, Coronavirus Disease 2019 (COVID-19), CDC CENTER FOR DISEASE CONTROL AND PREVENTION, https:/www.cdc.gov/coronavirus/2019-ncov/symptoms-testing/symptoms.html (last visited August 12, 2020).

Tajfel, Henri \& John Charles Turner. 1979. “An integrative theory of intergroup conflict.” In W. G. Austin \& S. Worchel (Eds.), The Social Psychology of Intergroup Relations. Monterey, CA: Brooks-Cole,

The InTERnATIONAL MONETARY Fund (IMF). 2020. A crisis like no other: An uncertain recovery. World Economic Outlook Update, (JUNE 2020).

The International MONETARy Fund (IMF). 2020. Policy Responses to COVID-19, https://www.imf.org/en/Topics/imf-and-covid19/Policy-Responses-to-COVID-19 (last visited August 13, 2020).

UN Response to COVID-19, UNITED NATIONS, https://www.un.org/en/coronavirus/UN-response (last visited August 12, 2020)

Veblen, Thorstein. 1899. The theory of the leisure class. New York: Macmillan. Retrieved at $\mathrm{http} / / / \operatorname{moglen}$. law.columbia.edu/LCS/theoryleisureclass.pdf.

Vereinte Nationen. 2020. A UN framework for the immediate socio-economic response to COVID-19, 2020. Retrieved at https://www.un.org/sites/un2.un.org/files/un_framework_report_on_covid-19.pdf. 